\title{
ECONOMIC EFFECTS AND REGULATORY LIMITS IN IMPLEMENTATION OF ENVIRONMENTAL TAXES
}

\author{
UDC 504.05/.06:336.2
}

\author{
Marija Magdalinović Kalinović*, Snežana Radukić \\ University of Niš, Faculty of Economics, Niš, Serbia
}

\begin{abstract}
Environmental protection presents one of the main goals of every socialresponsible economy. Environmental taxes based on the principle "the polluter pays", within the system of fiscal measures, present the basic instruments of environmental protection. The member states of the European Union (EU) belong to a group of the leading countries in the implementation of environmental taxes. Since the aim of the Republic of Serbia is to join EU, it is quite clear that in the future it will have to harmonize its normative acts with the EU legislation in the field of environmental protection. In the field of environmental protection in Serbia, we still have the implementation of more regulatory-normative measures in relation to the implementation of economic measures. Therefore, the comprehensive environmental tax reform is imminent. In the future, making the traditional tax rates green, presents the inevitability both in the system of regulatory and the system of institutional changes as well. In this paper, a brief review of the types of environmental taxes, which have already been implemented in EU has been given, as well as the current state in Serbia concerning the implementation of valid regulations in this field. When the importance of revenue from taxes and compensations for the environmental protection are taken into account, then a more responsible approach is necessary in statistic monitoring, recording, as well as in the process of purposeful spending of collected funds. When these conditions have been fulfilled, we can talk about a serious analysis of the state and efficient implementation of environmental taxes in the field of environmental protection.
\end{abstract}

Key words: environmental taxes, internalization of external effects, environmental protection, the Republic of Serbia.

Received August 11, 2016 / Revised August 18, 2016 / Accepted November 14, 2016 Corresponding author: Marija Magdalinović Kalinović, ${ }^{*} \mathrm{Ph} . \mathrm{D}$ student University of Niš, Faculty of Economics, Trg Kralja Aleksandra 11, 18000 Niš, Serbia E-mail:marijamk75@gmail.com 


\section{INTRODUCTION}

The interaction between a human and nature presents a dynamic process which is being changed in accordance with the civilization development. The biological existence of a human depends on healthy environment, so the existence of the ever-lasting tendency for his survival is quite clear. However, in accordance with economic, social, and global growth and the development of the society, the human requires, day by day, more natural and energetic resources, which leads firstly towards the excessive exploitation of natural resources, then secondly towards large-scale pollution and thirdly towards the destruction of the people's health. For that reason, higher rationalization in terms of exploiting natural resources is needed. There is a great need to define more effective measures and instruments within the field of environmental protection, of course, in order to protect it from further deterioration.

In the countries of EU, these environmental taxes have a very important role in the environmental protection. What is more, it is thought that it presents the only possible way for solving the problem of mass pollution and excessive exploitation of natural resources. As for these issues, the EU member-states are the leading ones, since it has always been known that the pollution of the environment has not only a national frame but it has become the international problem as well.

Environmental taxes present the instrument of internalization of the external effects. The basic goal of their implementation is the influence on the changes of economies entities behavior, that is, polluters. The implementation of taxes makes it possible to achieve the environmental goals in such a way that it eliminates the difference between the social and private costs. "The tax for each unit of emitted pollution must be equal to the marginal amount of the damage on the optimal level of pollution" (Pesic, 2012, p. 104). The polluter is now forced to analyze not only their private costs, but also the total social costs (of the social damage) caused by their business activity. "The goal of optimizing the allocation of resources means linking the externality costs by internalization to the ones which cause them to a great extend. Although the amount of externality costs can neither be exactly and precisely determined, nor all the causes, and since it is perfectly impossible to charge the externality costs of all found out causes, it is still possible the for the forces, which are alike the market ones, to engage in the service of environmental protection" (Radukic, Popovic, 2012, p. 51).

In the positive effects of applying the environmental taxes could also be included the achievement of the so-called "double dividends". It occurs as a result of applying the environmental taxes, as there is a possibility to decrease the tax liability of the labor force and to increase the taxation of "dirty" technologies. In that sense, the environmental tax reform has the positive effect not only in the field of environmental protection but it has a great economic importance. The EU member-states achieve their environmental goals by combining economic and regulatory measures and then, without any doubt the importance and significance of economic instruments must be emphasized.

In order for Serbia's accession to the European Union, the situational factors are being analyzed, the potentials, requirements which must be fulfilled in this field, as well as there is the necessity to carry out the tax reforms. In the paper, the types of environmental taxes in the EU member-states have been briefly described, their potential and efficiency, and then a short review of the existing situation in the Republic of Serbia is given. 


\section{TYPES OF ENVIRONMENTAL TAXES IN THE EUROPEAN UNION}

In the practice of the EU member-states, the commonly used instruments in this field are: environmental taxes, transferrable permits and subventions. The system of transferrable permits enables a certain degree of pollution up to the determined level, and the price of the permits is being determined on the base of the assessment of the future damage by the pollution. The polluters, which do less pollution than the level determined by permits, could sell their permits to the polluters that emit higher pollution than is the level determined by permits. This flexibility, which appears on the permits market, will make it possible for the companies to achieve the financial assets by selling their permits and then to invest them into purchase of some ecological and more efficient technologies. However, "the system of transferrable permits is not suitable for use in case of pollution emissions, which are not uniformly distributed in the space. It means that the selling permits by the polluters that are dealing in the rural area (or poorly populated settlements) to polluters that are dealing in the urban area will cause significantly higher damages" (Pesic, 2012, p. 112).

By the subvention policy, the state tries to decrease pollution, so that "subvention should be equal to the difference between the marginal social benefit from the decreased pollution and the marginal private benefit of the company which causes pollution" (Mojasevic, 2009, p. 205). "By the subvention policy, the allocative efficiency could be easily destroyed, as the total marginal social costs of production now include also the costs of subventions, and the company-polluter does not take into account the costs of subventions. The application of subventions does not lead to the decrease of economic activity. The consequence of all this, is the excessive production, that is, the excessive pollution" (Mojasevic, 2009, p. 205).

By strengthening the environmental consciousness in the seventies of the last century, the members-states of EU implemented the environmental taxes as the result of the defined principle "the polluter pays". This principle, besides the other two - the precautionary principle and the principle of including environmental policy into other polices of EU, was the foundation of the international environmental policy. The original implementation of these taxes, unfortunately, did not give the expected results because of the fact that their implementation in the beginning was considered to be the proper compensation for the pollution, that is, the permission for the pollution. However, with the increase of environmental tax rates and the definition of the responsibilities within the criminal-legal norm, these taxes become very important, especially in the Scandinavian countries.

The implementation of environmental taxes, as an instrument of environmental policy, requires the complementarity with the goals of other national policies (industry, agriculture, transport, employment, etc.). Taxes, first of all, should have incentive, but not a conflict character. At the same time, the accomplishment of environmental and economic goals presents the basic condition while choosing the appropriate economic instrument in the field of environmental protection.

Although the environmental pollution has got a global character and it implies a broader international consensus within the Union, the environmental taxes have got pronouncedly national feature and they are defined by the appropriate Directions (for example, the Direction on energy taxes). There are no supranational taxes within the Union. Although in the past there were these kinds of initiatives, primarily in the field of decreasing the emission of $\mathrm{CO}_{2}$ and energy consumption, there are still no taxes that would have such a feature. However, when it is taken into account that the environmental 
protection and pollution overcome the national borders and occur as global problems, a necessary definition of this kind of a tax in near future could be expected.

Within the European Union, there are the following environmental taxes (Eurostat):

- taxes on energy products, that are taxes on mineral oils, motor fuels, gasoline, diesel, heating oil, kerosene, petroleum, gas, electricity and taxes on gases that cause the greenhouse effect ;

- taxes on transportation, that is, the tax on the registration and usage of motor vehicles, the tax on import and selling motor vehicles, car insurance, the tax on using roads - road toll, the tax on using other transportation means;

- taxes on pollution referring to the air pollution $\left(\mathrm{CO}_{2}, \mathrm{NO}_{\mathrm{x}}, \mathrm{SO}_{2}\right)$, taxes on pesticide and artificial fertilizers, tax on waste that endanger the environment (bacteria, rubber, plastic bags);

- taxes on the resources including water treatment, usage of biological resources, exploitation of mineral raw materials (ores, oil, gas), exploitation of forests.

In the European Union, Sweden represents the country which is the leading one in introducing and implementing environmental taxes. Among the top leading countries today, besides Sweden and Denmark, are Germany, Finland, Great Britain, and the Netherlands. The European Union adopted in 2010 the Strategy "Europe 2020", by which it defined the priorities and goals in the field of market economy which is to be accomplished in the forthcoming period. One of the stated goals in the field of sustainable development is the efficient usage of resources and environmental protection. Within it, this strategy suggests the decrease of wage taxes, which would be compensated by higher taxes on dirty technologies, that is, by higher taxes on pollution. This is very important in the periods of high unemployment; this transfer of the tax burden from the labor force to the pollution would make it possible to achieve the so-called "double dividend", which would lead, on the one hand, to the decreased pollution, and on the other hand, to the increase of the employment. The decrease of the tax burden of the labor would make it possible to open additional jobs as well as the additional employment.

According to the latest announced data of European Commission (Environmental taxes in the EU, 2016) for the EU member-states the totally realized revenues on the base of environmental taxes, amounted to 343.6 billion euros in 2014. It is the increase of totally realized revenues according to this base, in relation to 2004, when it amounted to 282 billion euros. In the total environmental taxes, $76,5 \%$ goes to the revenue on the base of taxes on energy, then $19,9 \%$ goes to the revenue on the base of taxes on transportation and only $3,6 \%$ goes to the revenues on the base of the taxes on pollution and resources.

The share of environmental taxes in the total revenues from taxes and contributions is different in each of these member-states of EU. In the totally realized revenues from the environmental taxes, the predominant position belongs to the energy taxes in most of member-states of EU. For example, in Lithuania, Czech Republic, and Luxemburg, the energy taxes in 2014 amounted to over $90 \%$ out of the totally paid environmental taxes. The revenues from the taxes on the base of transportation in 2014, had a significant share in the totally paid environmental taxes (about 40\%) in Ireland, Denmark, Malta, Belgium, and Austria, while the revenues from the taxes on pollution and resources in 2014, with the share of over $10 \%$ out of the totally paid environmental taxes, were realized in Croatia, Holland, Estonia and Slovenia.

However, besides that total increase of fiscal revenues on the base of environmental taxes, their share in the total tax revenues was decreased from $6,8 \%$ in 2004 to $6,3 \%$ in 
2014 (Table 1). If we look at the period from 2004 to 2014, we can see that the share of these revenues was decreasing successively up to 2008, when it achieved the lowest level in the observed period $(6,03 \%)$. The reasons for this kind of movement of this category of revenues are: the occurrence of economic crisis, decreased scope of production, transfer to the more advanced and cleaner technologies, rationalization of using the resources with the tendency to use the renewable resources. Also, the share of these revenues in the total revenues is the indicator of the realization of the initiative for Europe, which spends resources efficiently (European Commission, Europe 2020). The basic goal of this Strategy is that the share of these taxes in the total share achieves at least $10 \%$ up to 2020.

Table 1 Share of environmental taxes in the total tax revenues (in \%)

\begin{tabular}{|c|c|c|c|c|c|c|c|c|c|c|c|c|}
\hline & 2003 & 2004 & 2005 & 2006 & 2007 & 2008 & 2009 & 2010 & 2011 & 2012 & 2013 & 2014 \\
\hline EU ( 28 countries) & 6.86 & 6.82 & 6.64 & 6.38 & 6.18 & 6.03 & 6.35 & 6.37 & 6.37 & 6.35 & 6.33 & 6.35 \\
\hline Belgium & 5.47 & 5.66 & 5.64 & 5.24 & 5.17 & 4.91 & 5.11 & 5.13 & 5.15 & 4.79 & 4.52 & 4.53 \\
\hline Bulgaria & 9.51 & 9.76 & 9.58 & 9.46 & 10.11 & 10.69 & 10.49 & 10.6 & 10.59 & 10.1 & 10.03 & 9.84 \\
\hline Check Republic & 6.9 & 7.05 & 7.24 & 7.05 & 6.74 & 6.85 & 7.19 & 7.03 & 6.99 & 6.56 & 6.15 & 6.22 \\
\hline Denmark & 10.54 & 10.75 & 10.25 & 10.07 & 10.21 & 9.32 & 8.88 & 8.92 & 8.92 & 8.67 & 8.92 & 8.18 \\
\hline Germany & 6.88 & 6.72 & 6.53 & 6.29 & 5.81 & 5.68 & 5.95 & 5.81 & 5.83 & 5.59 & 5.38 & 5.24 \\
\hline Estonia & 6.11 & 6.73 & 7.58 & 7.17 & 7 & 7.37 & 8.42 & 8.82 & 8.65 & 8.61 & 8.09 & 8.28 \\
\hline Ireland & 7.86 & 8.28 & 8.35 & 7.7 & 7.94 & 7.93 & 8.06 & 8.79 & 8.74 & 8.38 & 8.5 & 8.17 \\
\hline Greece & 6.75 & 6.9 & 6.52 & 6.34 & 6.35 & 6.01 & 6.32 & 7.93 & 8.25 & 8.91 & 10 & 10.24 \\
\hline Spain & 6.04 & 5.73 & 5.4 & 5.08 & 4.86 & 5.06 & 5.39 & 5.22 & 5.05 & 4.87 & 5.77 & 5.5 \\
\hline France & 4.69 & 4.91 & 4.68 & 4.53 & 4.4 & 4.33 & 4.45 & 4.48 & 4.45 & 4.41 & 4.47 & 4.47 \\
\hline Croatia & 11.12 & 10.95 & 10.62 & 10.23 & 9.95 & 9.34 & 9.26 & 10.11 & 9.38 & 8.87 & 9.58 & 10.51 \\
\hline Italy & 7.51 & 7.25 & 7.44 & 7.14 & 6.57 & 6.22 & 6.7 & 6.74 & 7.36 & 8.04 & 7.89 & 8.28 \\
\hline Cyprus & 12.01 & 12.32 & 10.58 & 9.63 & 8.7 & 8.69 & 8.76 & 8.67 & 8.68 & 8.13 & 8.63 & 9.01 \\
\hline Latvia & 8.31 & 8.93 & 9.07 & 7.79 & 6.86 & 6.67 & 8.48 & 8.75 & 8.9 & 8.59 & 8.6 & 9.26 \\
\hline Lithuania & 9.68 & 9.3 & 7.85 & 5.97 & 5.82 & 5.34 & 6.68 & 6.46 & 6.2 & 6.09 & 6.04 & 6.13 \\
\hline Luxembourg & 7.29 & 8.19 & 7.84 & 7.36 & 7.1 & 7.05 & 6.58 & 6.38 & 6.36 & 6.15 & 5.65 & 5.23 \\
\hline Hungary & 7.41 & 7.68 & 7.48 & 7.62 & 7 & 6.76 & 6.7 & 7.36 & 7.17 & 7.04 & 6.8 & 6.79 \\
\hline Malta & 10.72 & 9.44 & 9.74 & 9.99 & 10.85 & 10.18 & 9.78 & 9.32 & 9.53 & 8.81 & 8.26 & 8.51 \\
\hline Holland & 9.51 & 9.83 & 10.06 & 9.96 & 9.44 & 9.56 & 9.93 & 9.79 & 9.64 & 9.12 & 9.04 & 8.96 \\
\hline Austria & 6.36 & 6.37 & 6.31 & 6.03 & 5.86 & 5.7 & 5.76 & 5.72 & 5.91 & 5.78 & 5.63 & 5.63 \\
\hline Poland & 7.72 & 8.54 & 8.11 & 7.89 & 7.9 & 7.74 & 8.05 & 8.22 & 7.95 & 7.82 & 7.5 & 7.82 \\
\hline Portugal & 9.4 & 9.76 & 9.37 & 8.9 & 8.62 & 7.82 & 8.15 & 7.96 & 7.16 & 6.8 & 6.48 & 6.59 \\
\hline Romania & 8.4 & 8.59 & 7.15 & 6.76 & 7.05 & 6.32 & 7.1 & 8 & 6.88 & 7.08 & 7.47 & 8.76 \\
\hline Slovenia & 8.65 & 8.67 & 8.29 & 7.86 & 7.97 & 8.06 & 9.57 & 9.75 & 9.43 & 10.32 & 10.74 & 10.61 \\
\hline Slovakia & 7.36 & 7.77 & 7.48 & 7.64 & 7.11 & 6.91 & 6.67 & 6.52 & 6.36 & 6.12 & 5.72 & 5.76 \\
\hline Finland & 7.28 & 7.47 & 7.06 & 6.91 & 6.41 & 6.3 & 6.19 & 6.57 & 7.18 & 6.98 & 6.71 & 6.57 \\
\hline Sweden & 6.05 & 5.88 & 5.84 & 5.68 & 5.59 & 5.83 & 6.08 & 6 & 5.66 & 5.65 & 5.51 & 5.18 \\
\hline Great Britain & 7.65 & 7.4 & 6.93 & 6.54 & 6.79 & 6.49 & 7.5 & 7.47 & 7.25 & 7.39 & 7.47 & 7.54 \\
\hline
\end{tabular}

Source: Eurostat, Shares of environmental and labour taxes

in total rax revenues from taxes and social contributions.

This level of collecting environmental taxes is considered to be insufficient so that there are constant initiatives that the existing tax system should be more stimulating in terms of the standpoint of the goals of environment protection as well as the economy growth and opening new jobs. The improvement of the environmental tax system implies the following: abolishing the distorting taxes and subventions; the change of the existing tax structure and the introduction of new environmental taxes. 
Distorting taxes and subventions are especially present in the field of transport where some definite tax reliefs are given for using cars, which leads to the increase of traffic, that is, to the increase of pollution. Here are also the subventions for air-companies, coal mines, etc.

The change of the existing tax structure implies the fact that in the price of particular products is included the amount of environmental taxes with the tendency to extend it to all the products which pollute the environment. One more thing is true, too: the differentiation of taxation enables the implementation of lower tax rates on the products which are less harmful for the environment.

The introduction of new environmental taxes should enable the redistribution of the tax burden between the labor and natural resources so that it presents the basic measure in accomplishing the goals of environmental policy. This measure should encourage the polluters to decrease the emitted pollution (Ilic-Popov, 2000).

Environmental protection presents one of key values in the European Union, where its members have defined the clear policy and ambitious goals which should be fulfilled in terms of energy saving, decreased gas emission of the greenhouse and using the renewable energy sources up to 2020 . However, besides all these efforts, the statistics shows that "the level of gas emission of the greenhouse is increasing so that in the period from 2010 to 2020, the existing projects point to the fact that it will reach the emission gas level of more than $2 \%$ than it was in 2005 , that is, it will be only $6 \%$ lower than the emission of the level in 1990" (Kosonen and Nicodeme, 2009, p. 1). Therefore, it is quite clear that the member-states could achieve the given goals in the field of environmental protection only by strong state intervention and commitment. It, first of all, refers to the changes of tax rates, the extent of the tax scope so that it would be possible to include in the tax base as many emitters of pollution as possible, but at the same time, enables the longer transiting period in order to help industry, that is economy, to adjust to the new system of taxation.

\section{ECONOMIC INSTRUMENTS OF ENVIRONMENTAL PROTECTION IN THE REPUBLIC OF SERBIA}

Taking into consideration the process of joining of the Republic of Serbia to the European Union, it is clear that Serbia will have to adjust its national legislation in this field to the legislation of the European Union. Although Serbia, in the previous period of time, did important shifts in relation to the last period of time, in the coming years, a very intensive process of adjusting and adopting new laws will engage Serbia, as well as in building up the necessary infrastructure in this field. Up to the end of 2016 the opening of the negotiating Chapter 27 "Environment and Climatic Changes" with the European Union is expected (Government of the Republic of Serbia)

Financing environmental protection is one of the key issues in the process of adjusting the national legislation to the regulations of the European Union. The introduction of the stable and effective system of financing is the basic pre-condition for preserving and improving of the environment. In Serbia, a decentralized system of environmental financing has been developed, which implies the following: the budgetary resources funds; the budget of the autonomous province and units of local self-government ; the financial resources of some other international organizations, institutions and bodies; the local and foreign legal and physical persons; the funds of the European Union; donations; grants; supports, etc. The environmental financing has been provided by the legally defined 
principles "the user pays", "the polluter pays", as well as the principle of responsibility. The fact that presents the chief characteristic of the environmental financing is the insufficiency of financial resources.

In addition to all these things, when we talk about the implementation of the economic instruments in the environmental protection, the revenues that have been collected from their implementation are often insignificantly small although there is a high degree of environmental pollution and degradation. The causes are manifold, but the common are stated as the inconsistency in implementing these instruments and high degree of tolerance when the matter is about polluters, that is, big companies, which have been in difficult economic position for years, that is, in the process of restructuring.

Economic instruments in the field of environmental protection are aimed at not only the collection of some public revenues but also at achieving a positive influence on the behavior of legal and physical persons on the whole, in terms of decreasing, that is, preventing pollution. The purpose of their implementation is the change of society behavior on the whole and making people aware of the consequences caused by pollution. Therefore, the clear and efficient environmental policy requires good and clearly defined economic instruments.

In Serbia, the economic instruments in the field of environmental protection were introduced in 2004 on the base of the Law on Environmental Protection. By a series of by-laws, their implementation has been defined. The economic instruments, which have been implemented, include the compensations and incentives.

When we talk about compensations, there are several types (Law on budget system and particular non-fiscal laws):

- compensation for using natural resources,

- compensation for environmental pollution,

- compensation for environmental pollution in the regions of special state interest and

- local self-government units compensation for protection and improvement of environment.

The compensation for using natural resources is to be paid by the users of natural resources and they are to bear all the expenses for rehabilitation and recultivation of the degraded areas in accordance with the Law. These compensations are obligatory for using mineral raw materials, water, forests, soil, hunting and fishing. The user of natural resources is obliged to pay this compensation.

The compensation for environmental pollution is paid by the polluter and it is determined on the basis of the type of polluting for: the emissions from the particular sources of polluting, the emissions of the produced or dumped waste, as well as for the harmful substances contained in the raw materials, intermediate goods or a product. The Government of the Republic of Serbia, by the Direction on types of polluters, the standards for calculating the compensation for polluting the environment as well as obligors, on the base of the height and way for calculating and paying the compensation (2005), determines the criteria for the calculation of the compensation for polluting, the obligors, and finally, the height and way of calculating and paying the compensation. The assets obtained by collecting these compensations in the amount of $60 \%$ present the revenue of the budget of the Republic of Serbia and $40 \%$ presents the revenue of the units of local self-government.

Compensation for the produced or dumped waste is also determined on the annual level and depends on the type, quantity and features of the waste. The paying obligor is the producer, i.e. disposer of waste from the plant for which it has been issued the integrated permits. It is calculated per ton of waste annually. 
Liable to pay the compensation for substances which damage the ozone layer, are the importers of these substances. This compensation is calculated per kilogram of the imported substance.

Compensation for environmental pollution in the areas of particular state interest declared by the Government of the Republic of Serbia_also presents the revenue of Republic budget in the amount of $80 \%$ while $20 \%$ goes to the budgets of local selfgovernments. By the Law on Protecting Nature (2009), nature is defined as the benefit of common interest and its protection has been arranged. By the Law, there have been also defined the basic elements for calculating this compensation, and by the Direction on closer criteria, the way of calculating and the procedure of paying the compensation for using the protected area (2010), are being given in the details of the elements and the way of calculating. The assets collected from the paid compensations are used especially for the improvement and development of the protected areas. Responsible for paying these fees, is an entity who undertakes one of the following activities in the protected area (Law on Protecting Nature, 2009):

- mining, trading, hospitality, industry, civil engineering, traffic, transport, crafts, offering services;

- using vehicles in the protected area;

- using non-commercial facilities for holidays in these areas;

- using services, facilities and other structures, as well as names, and logotype signs of the protected area;

- visiting the protected areas, as well as visiting the structures on these areas.

Compensation for protecting and improving of environment is the compensation which the local self-government can prescribe within its jurisdiction on the base of: using the habitable and business premises, using the soil for performing activities, then for the activities that have an influence on environment, and the ones which are determined by the Government, transportation of oil, oil derivatives and other dangerous substances on the territory of the unit of local self-government with the status of endangered environment. Criteria for calculating and the highest amounts for these compensations are determined by the Direction on Criteria for Determining the Compensation for the Protection and Improvement of the Environment and the Highest Amount of the Compensation (2009). This compensation presents the source revenue of the units of local self-government. In 2014, the revenues from the compensation for the environmental protection amounted to $0,27 \%$ of the totally achieved GDP, that is, $10.610,52$ million dinars and they were increased in relation to 2013, when they amounted to 7.962 million dinars (Environmental Protection Agency 2015).

The Fund for Environmental Protection was founded by the Law on Fund for Environmental Protection (2009). The basic role of the Fund was to provide the financial assets for stimulating and improving the environment, then the purposeful investment in the projects for environmental protection, as well as managing and mediating in the projects of energetic efficiency with the aim of sustained development and using renewable sources of energy. The revenue structure was also determined, which belonged to the Fund and the units of local self-government depending on the type of the compensation. The basic economic instruments for providing the financial assets were: the compensation for environmental pollution, and the compensation for transportation of wild flora and fauna. The Fund started working in 2009, and it ceased existing in September 2012, with the 
explanation that there was no transparency in spending collected assets. When the Fund stopped operating, all revenues, based on this principle, became the revenues of the Fund of the Republic of Serbia. The foundation of a new budget, "green" one is anticipated by the changes of the Law on Environmental Protection, precisely, till the end of 2016.

\section{IDENTIFIED PROBLEMS AND WEAKNESSES OF THE COMPENSATION SYSTEM FOR ENVIRONMENTAL PROTECTION IN THE REPUBLIC OF SERBIA}

The compensations, defined on the basis of the national level by the Law on Environmental Protection, are various and it can be said, with a double character. One group of compensations has got the character of classical compensations, when it is about using and exploiting natural resources, while the second group of compensations consists of compensations which have got the character of taxes (Bisic, 2011). These corrective taxes present the additional tribute (tax) to the economic units, which, by their economic activities, cause the environmental pollution. The implementation of these instruments should provide a more rational exploitation of natural resources, the decreasing of activities and operations which cause the environmental pollution and purposeful usage of collected assets on this ground (Bisic, 2011). Compensations would primarily have the function of regulating the external effects and only then they are the function of budget revenues. This is of particular importance when we talk about negative external effects, when the producer does not bear the full production costs, but completely takes the revenue. In case that there is no adequate and efficient regulation, the scope of production is bigger from the socially-optimal level and with long-lasting consequences, such as the exhaustion of natural resources, excessive pollution, etc. Accordingly, compensation as a price of use of a natural resource or service should ensure that the user bears the full costs of the use of these resources.

The compensation for the pollution represents a typical environmental tax, but, on the other hand, the compensation for the promotion and protection of the environment is neither the compensation nor the tax. Funds raised on this basis have exclusive fiscal nature and they are frequently used for undesignated purposes. Income from compensation based on the exploitation of mineral resources for years has experienced an exceptionally small share of total revenue. The consequence of this situation is, above all, difficult economic situation of companies in the mining sector, which have been in the process of restructuring. Therefore, when it is the matter of this type of compensation, it is not certain whether it is justified to apply it as a percentage of net revenue of the smelter (5\%) or, to take it as an absolute outcome per ton of exploited mineral raw materials.

Therefore, well based and defined set of economic instruments has a great importance. Onthe one hand, they should be defined in such a way so that they can affect the change of economic entity's behavior, and on the other hand, to define them on such a level that will not affect its competitiveness. The basic aim of their implementation is, first of all, the change of social behavior of the entity in terms of decreasing pollution and not only being the source of fiscal revenues. It is clear that it is the matter of a very complex procedure for defining the height, criteria, basis, the obligor who pays, etc.

However, the system of instruments should not be based only on compensations, taxes and penalties. It could be and must be considered through the introduction of economic incentives, such as the exemption from paying the compensation or the tax relief for those economic entities which invest in the decrease of pollution, that is, those which invest in 
cleaner technologies. In that sense, in the USA, since the middle of the twentieth century, the tax investment loans have been used as an instrument of the economic policy for raising the competitiveness of American economy. In other words, the incentive is given to the economic entities so that, for the given percentage of investing costs at the moment of purchasing the new equipment, they decrease the tax rate, and in that way obtain the subvention for investment.

The definition of an obligor who pays the compensation and eco-taxes has a great importance. It is necessary to make a complete register of polluters, that is, the obligors who pay compensations, and not only to point out the existence of the obligation to pay compensations by big economic systems with integrated permits, who, because of a very difficult economic position, most commonly perform their responsibilities on this basis in an undisciplined manner.

It is also true that the system of financing the environmental protection in Serbia presents one of the basic problems in implementing environmental reforms. It is, in fact, a decentralized system, which relies, to a great extent, on the budget assets, the international financing support and subventions. The existing system of financing must be upgraded as the higher financial potential is a pre-condition of attaining the environmental goals. Even such insufficient assets are mostly used inappropriately, that is, they are not used for the decrease of pollution. The lack of coordination and monitoring activities is present not only when it is the question of needs in this field, but also the determination of the occurred damages caused by pollution, then the lack of legal and institutional regulations (for example, foundation and then the termination of the eco-fund) etc. The fact is, we can hardly realize the real financing needs in the field of environmental protection, and that we are unable to determine the range of destroyed environment of both current and the pollution occurred in the previous period.

\section{THE SUGgestion OF MEASURES FOR IMPROVING THE COMPENSATION SYSTEM IN THE FIELD OF ENVIRONMENTAL PROTECTION IN THE REPUBLIC OF SERBIA}

The success in managing the policy of environmental protection implies clearly defined instruments for environmental protection. The ultimate solution could be the adoption of the Law on Environmental Taxes which would include the current compensations, as the essential taxes, and in that way perform the more objective categorization (Bisic, 2011). The combination of fiscal and non-fiscal instruments would present a good set of economic measures. Measures and instruments of environmental policy cannot be separated from economic policy.

Every approach in solving the problem of externalities, no matter if it is the matter of private agreement or a state regulation and the policy of incentives (especially with the industrial pollution), has got its positive and negative characteristics. The effective system presents the combination of these two ways in solving this problem.

When there is a large-scale industrial pollution, the systems with integrated permits, which are mostly the obligors of payment of compensations, usually do not perform their responsibilities due to the economic situation in which they are. This must be changed in terms of more disciplined and responsible paying of these compensations and taxes along with the implementation of the appropriate penalty system. The extension of the list of obligors, that is, the identification of all obligors no matter if they are legal or physical 
persons who are the polluters of the environment, is the pre-condition for running good policy of environmental protection. The implementation of economic instruments should lead to the socially acceptable behavior of all entities and not have as its main goal the collection of budget assets. Therefore, the growth of assets of eco-funds is not the goal by itself, but on the contrary, as a means of decreasing the pollution. A good set of economic instruments implies neither too high nor too low compensations and taxes, determined on the base of the most objective parameters of pollution (soil, water, air, human health, flora and fauna).

\section{CONCLUSION}

The harmonization of Serbian legislation with the EU regulations in the field of environmental protection is inevitable. In the forthcoming period, this process of adjustment will require a complete analysis of both positive and negative effects of environmental taxes. By the tax, the polluter is forced to internalize the negative external effects not only because of the respect of the principals of equity, but because of the principals of efficiency and proper allocation of resources. The implementation of these taxes should lead to the changes of behavior of all entities, and not be the basis for collecting budget assets. The existence and the growth of eco-funds are not goals in themselves, but the basic goal is the decrease of pollution when a long-term period of time is taken into consideration. The introduction of cleaner technologies is financially more required, especially for less developed countries and that is why their progress in developing the environmental reforms is slow.

In order to make an objective assessment of the pollution range, as well as the needs in the field of environmental protection, it is necessary to develop a good system of registration of polluters, monitoring the damages caused by pollution, recording the statistical and financial records of the effects of polluting and the benefits from the investment in environmental infrastructure projects. The ecological-ethical principle implies the rational expenditure and management of the resources nowadays so that it would be possible to provide the principle of sustainable development in the future. This principle implies that today's generations, by satisfying their own needs, by using the resources and environment, must not endanger that same right because of future generations. Finally, the consistent and legal implementation of eco-taxes and other economic instruments in this field is the only way to achieve sustainable development in the future.

Acknowledgement: The paper is a part of the research done within the project 44007 by Ministry of Education, Science and Technological Development of the Republic of Serbia.

\section{REFERENCES}

Agencija za zaštitu životne sredine, (2015). Izveštaj o ekonomskim instrumentima za zaštitu životne sredine u Republici Srbiji za 2014. god. Beograd: Ministarstvo poljoprivrede i zaštite životne sredine.

Bisić. M, (2011). Sistem naknada za korišćenje prirodnih bogatstava i raspodela prihoda između centralnog $i$ lokalnih nivoa vlasti, Beograd: Stalna konferencija gradova i opština, Savez gradova i opština Srbije.

European Commission, (2010). Europe 2020, Strategy for smart, sustainable and inclusive growth, Brussels, COM (2010) 2020 final, Retrieved from: http://eulex.europa.eu/LexUriServ/LexUriServ.do?uri=COM: 2010:2020:FIN:EN:PDF, Accessed on: 03.06.2016. 
Eurostat, (2016). Environmental taxes in the EU, 78/2016, Retrieved from: http://ec.europa.eu/eurostat/documents/ 2995521/7236510/8-22042016-BP-EN.pdf/b910e804-e410-4b9c-b9ab-1893398e2a2d, Accessed on: 02.06 .2016 .

Eurostat, Environmental taxes, Retrieved from: http://ec.europa.eu/eurostat/web/environment/environmentaltaxes, Accessed on: 06.06.2016.

Eurostat, Shares of environmental and labour taxes in total rax revenues from taxes and social contributions, Retrieved from: http://ec.europa.eu/eurostat/tgm/table.do?tab=table\&init=1\&language=en\&pcode=tsdgo410\& plugin=1, Accessed on: 02.06.2016.

Government of Republic of Serbia, Retrieved from: http//www.srbija.gov.rs/vesti/vest.php?id=265744, Accessed on: 02.06.2016.

Harris, J. M. (2009). Ekonomija životne sredine i prirodnih resursa: savremeni pristup. Beograd: Data status.

Ilić-Popov, G. (2000). Ekološki porezi. Beograd: Pravni fakultet Univerziteta u Beogradu.

Kosonen. K. \& Nicodeme. G, (2009). The Role of Fiscal Instruments in Environmental Policy (CESinfo working paper, No. 2719), pp. 1-30, Retrieved from: http//ssrn.com/abstract=1437501, Accessed on: 02.06.2016.

Mojašević, A. (2009). Ekonomska analiza ekološkog prava i politike. In: Zbornik radova Pravnog fakulteta u Nišu (Eds.), no. 53 (pp. 199-218). Niš: Pravni fakultet.

Pešić, R. (2012). Ekonomika životne sredine i prirodnih resursa. Beograd: Zavod za udžbenike.

Radukić, S., Popović, Ž. (2012). Značaj koncepta internalizacije eksternalija u politici zaštite životne sredine. In: Nauka i svetska ekonomska kriza (Eds.) (pp. 45-53). Niš: Ekonomski fakultet Univerziteta u Nišu.

Uredba o bližim kriterijumima, načinu obračuna $i$ postupku naplate naknade za korišćenje zaštićenog područja, Sl. Glasnik RS, br. 43/2010.

Uredba o kriterijumima za utvrđivanje naknade za zaštitu i unapređivanje životne sredine i najvišeg iznosa naknade, Sl. Glasnik RS, br. 111/2009.

Uredba o vrstama zagađivanja, kriterijumima za obračun naknade za zagađivanje životne sredine $i$ obveznicima, visini i načinu obračunavanja i plaćanja naknade, Sl. Glasnik RS, br. 113/2005, 6/2007, 8/2010, 102/2010, 15/2012, 91/2012, 91/2012, 30/2013 - dr. pravilnik, 25/2015 - dr. pravilnik.

Zakon o budžetskom sistemu i posebnim nefiskalnim zakonima, Sl. Glasnik, br. 54/2009, 73/2010, 101/2010, 101/2011, 93/2012, 62/2013, 63/2013 - ispr., 108/2013, 142/2014, 68/2015 - dr. zakon i 103/2015.

Zakon o Fondu za zaštitu životne sredine, Sl. Glasnik RS, br. 72/09 i 101/11.

Zakon o zaštiti prirode, Sl. Glasnik RS, br. 36/2009, 88/2010, 91/2010 - ispr. i 14/2016.

Zakon o zaštiti životne sredine, Sl. Glasnik, br. 135/2004, 36/2009, 36/2009- dr. zakon,, 72/2009 - dr. zakon, 43/2011 - odluka US i 14/2016.

\section{EKONOMSKI EFEKTI I REGULATORNA OGRANIČENJA U PRIMENI EKOLOŠKIH POREZA}

Zaštita životne sredine predstavlja jedan od ključnih ciljeva svake društveno-odgovorne ekonomije. Ekološki porezi po principu "zagađivač plaća", u sistemu fiskalnih mera predstavljaju osnovne instrumente zaštite životne sredine. Zemlje članice Evropske unije (EU) pripadaju grupi vodećih zemalja kada je u pitanju primena ekoloških poreza. S obzirom da Republika Srbija ima za cilj priključenje EU, jasno je da će u budućnosti morati da usaglasi svoje normativne akte sa zakonodavstvom EU u oblasti zaštite životne sredine. U Srbiji u oblasti zaštite životne sredine još uvek imamo primenu više regulatorno-normativnih mera $u$ odnosu na primenu ekonomskih instrumenata. Dakle, sveobuhvatna ekološka poreska reforma tek predstoji. U budućnosti ozelenjavanje tradicionalnih poreskih stopa predstavlja neminovnost kako u sistemu regulatornih, tako i u sistemu institucionalnih promena. U radu je dat kratak osvrt na vrste ekoloških poreza koji su u primeni u EU, kao i trenutno stanje u Srbiji kada je reč o primeni važećih propisa u ovoj oblasti. S obzirom na značaj prihoda od taksi i naknada za zaštitu životne sredine, potreban je odgovorniji pristup u statističkom praćenju, izveštavanju, kao i u procesu namenskog trošenja prikupljenih sredstava. Tek nakon ispunjenja ovih uslova možemo govoriti o ozbiljnijoj analizi stanja i efekata primene ekoloških poreza u oblasti zaštite životne sredine.

Ključne reči: ekološki porezi, naknade za zagađenje, internalizacija eksternih efekata, zaštita životne sredine, Republika Srbija. 